\title{
PENGARUH FAKTOR GEOMETRIK SUMUR RESAPAN TERHADAP PERENCANAAN DIMENSI SUMUR RESAPAN DAN PENGURANGAN LIMPASAN PERMUKAAN
}

\author{
Sri Amini Yuni Astuti, ${ }^{1, *}$ \\ ${ }^{1, *)}$ Jurusan Teknik Sipil, Fakultas Teknik Sipil dan Perencanaan, Universitas Islam Indonesia \\ Email: amini_yuni@uii.ac.id
}

\begin{abstract}
To solve the problem of flooding and to conserve groundwater, many infiltration wells have been built. The dimensions and number of infiltration wells are influenced by the geometric factor of an infiltration well. Therefore, this paper discusses the influence of infiltration well geometric aspect on the dimensional planning and the number of infiltration wells needed and feasible to build based on the existing land limitations. The planning of infiltration wells uses the Sunjoto method. The study location is in the UII integrated campus. The rainfall data were taken from the Prumpung station in 1998 - 2016. The more significant the infiltration well geometric factor, the smaller the number and dimensions of infiltration wells. For example, in the D3 Ekonomi complex, for a type of infiltration well with a diameter of $1.5 \mathrm{~m}$ and a height of $4 \mathrm{~m}$, with $F=2 \pi R$, eight units are needed, while an infiltration well with $F=\pi^{2} R$ require seven units. Likewise for other complexes. With the limited land available, the greater the infiltration well geometric factor used, the reduction in surface runoff is not much change, almost the same, namely $59.73 \%$ with $F=2 \pi R($ or $F=4.7124 \mathrm{~m})$ and $59.79 \%$ with $F=\pi^{2} R($ or $F=7.4022 \mathrm{~m})$.
\end{abstract}

Keywords: geometric factor, dimensions of infiltration wells, Sunjoto method, reduction in surface runoff

\section{PENDAHULUAN}

Air dibutuhkan oleh manusia untuk memenuhi berbagai kebutuhan hidupnya yaitu: untuk kebutuhan air baku, industri, kebutuhan rumah tangga, penyiraman tanaman, pengairan, dan pembilasan limbah. Sumber air bersih dapat diperoleh dari air permukaan, air tanah dan air hujan. Dari ketiga sumber air bersih tersebut, air tanah mempunyai kelebihan dibanding dengan yang lain. Secara higienis lebih baik karena sudah mengalami proses penyaringan secara alamiah, cadangan dan kualitasnya juga relatif tetap sepanjang tahun, dan apabila air tanah tersedia di tempat tersebut, pengambilannya tanpa memerlukan peralatan mahal.

Untuk memenuhi kebutuhan air tersebut maka usaha konservasi air tanah perlu dilakukan. Banyak bangunan yang telah dikenal sebagai upaya konservasi air tanah, antara lain kolam resapan, sumur resapan, saluran resapan, taman resapan, dan biopori.

Makalah ini menjelaskan tentang salah satu bangunan konservasi air tanah, sumur resapan yaitu tentang pengaruh faktor geometrik sumur terhadap dimensi sumur dan pengurangan limpasan permukaan. Hal ini penting dilakukan, karena terkadang sering digunakan faktor geometrik yang sudah populer, tanpa mengetahui pengaruh faktor geometrik yang lain.

Untuk lokasi studi diambil kasus sistem drainase di area Kampus Terpadu UII yang bermuara di kali Kimpulan.

Dari uraian di atas dapat dikemukakan permasalahannya adalah seberapa besar pengaruh faktor geometrik sumur terhadap dimensi sumur resapan dan terhadap 
pengurangan limpasan permukaan di kawasan tersebut?

Beberapa penelitian terdahulu diantaranya yaitu Teknologi Sumur Resapan Dalam Kajian Pemaparan Hidrograf Banjir Sub DAS Ciujung (Wigati dan Ichwan, 2014), Rancangan Sumur Resapan Air Hujan sebagai Upaya Pengurangan Limpasan di Kampung Babakan, Cibinong, Kabupaten Bogor (Bahunta dan Waspodo, 2019), menyimpulkan bahwa sumur resapan dapat mengurangi limpasan permukaan, dan selanjutnya dapat menyelesaikan masalah genangan dan banjir.

Pada penelitian Konservasi Air Tanah melalui Pembuatan Sumur Resapan Air Hujan Di Kelurahan Maradekaya Kota Makassar (Aziz, A dkk, 2016), menyatakan bahwa dengan adanya sumur resapan air hujan akan memperbaiki kualitas air tanah sumur dangkal dan juga untuk melestarikan ketersediaan air tanah di daerah tersebut.

Sedangkan penelitian Prasojo, (2015), menyatakan bahwa metode Sunjoto (2015) membutuhkan lebih sedikit jumlah sumur resapan dari pada jika menggunakan metode SNI 03-2453-2002.

Selanjutnya kinerja sumur resapan juga sudah diteliti dalam menerima hujan yang terjadi sesungguhnya, yaitu sebesar 96,67 \% (dengan mempertimbangkan ketersediaan lahan) pada Kinerja Sumur Resapan Kampus Terpadu UII Tahun 2007 - 2016 (Astuti, 2020).

Dari beberapa penelitian di atas, belum pernah diteliti pengaruh faktor geometrik sumur resapan. Hal tersebut sangat penting supaya dalam merancang sumur resapan dapat menggunakan faktor geometrik bentuk sumur yang tepat.

\section{DEBIT RANCANGAN}

Selama ini dalam hidrologi dikenal beberapa cara analisis untuk memperoleh besaran banjir, antara lain cara empirik, statistik dan analisis dengan model. Cara statistik dianggap paling baik, karena mendasarkan analisis pada data hujan atau data debit yang terukur di sungai. Sudah barang tentu sangat tergantung dari kualitas data yang tersedia. Kualitas data yang tidak baik tidak dapat diharapkan hasil analisis yang baik. Dalam ilmu statistik dikenal beberapa macam distribusi frekuensi dan empat jenis distribusi yang banyak digunakan dalam bidang hidrologi adalah Distribusi Normal, Log Normal, Log Person III dan Gumbel (Triatmojo, 2013).

Dari analisis frekuensi diperoleh hujan rancangan dengan kala ulang tertentu yang digunakan untuk menghitung intensitas hujan (I). Besar intensitas hujan dicari menggunakan rumus Mononobe seperti berikut ini.

$I=\frac{R_{24}}{24}\left(\frac{24}{t}\right)^{2 / 3}$

dengan $\mathrm{I}=$ intensitas hujan $(\mathrm{mm} / \mathrm{jam}), \mathrm{t}=$ durasi hujan dominan atau waktu konsentrasi (jam) dan $\mathbf{R}_{24}=$ curah hujan maksimum harian $(\mathrm{mm})$ atau hujan rancangan dengan kala ulang tertentu.

Durasi hujan (t) pada Pers. (1) menggunakan waktu konsentrasi $\left(t_{c}\right)$. Untuk memperkirakan waktu konsentrasi bisa menggunakan persamaan yang telah dikembangkan oleh Kirpich (1940) dalam Suripin (2004), yang dapat ditulis sebagai berikut.

$t_{c}=\left(\frac{0,87 \cdot L^{2}}{1000 \cdot S_{0}}\right)^{0,385}$

dengan $t_{c}=$ waktu konsentrasi $(\mathrm{jam}), \mathrm{L}=$ panjang saluran utama dari hulu sampai penguras $(\mathrm{km})$ dan $\mathrm{So}=$ kemiringan rata-rata saluran utama.

Debit rancangan dicari menggunakan metode Rasional. Metode ini digunakan untuk Daerah Aliran Sungai (DAS) berukuran kecil atau kurang dari 300 ha (Suripin, 2004). Metode Rasional dikembangkan berdasarkan asumsi bahwa hujan mempunyai intensitas seragam dan merata di seluruh DAS selama paling sedikit sama dengan waktu konsentrasi $\left(t_{c}\right)$ 
DAS. Persamaan matematik metode Rasional dapat dilihat sebagai berikut.

$$
Q_{p}=0,002778 \text {.C.I.A }
$$

Dengan $Q_{p}=$ debit rancangan $\left(\mathrm{m}^{3} / \mathrm{s}\right), \mathrm{C}=$ koefisien limpasan permukaan, $\mathrm{I}=$ intensitas hujan ( $\mathrm{mm} / \mathrm{jam})$ dan $\mathrm{A}=$ luas DAS (ha) atau luas atap (ha).

\section{SUMUR RESAPAN}

Sunjoto (2015) mengusulkan formula untuk merencanakan kedalaman suatu sumur resapan. Hujan yang jatuh di atap bangunan dialirkan masuk ke sumur resapan. Mekanisme aliran adalah aliran tidak tetap (unsteady flow).

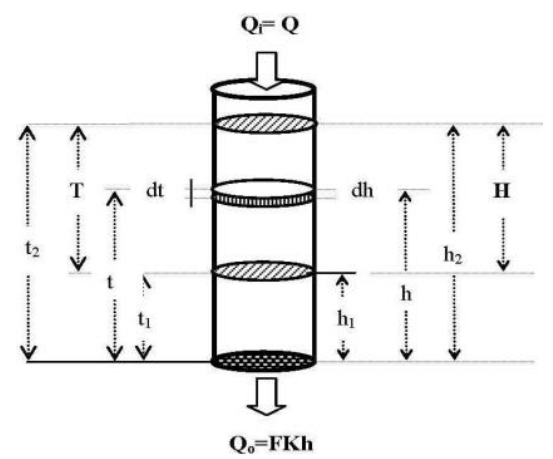

Gambar 1. Pendekatan aliran tidak tetap sumur resapan

$\mathrm{Q}_{\mathrm{i}}$ adalah debit aliran akibat hujan yang jatuh di atap bangunan $=\mathrm{Q}$

$\mathrm{Q}_{0}$ adalah debit aliran yang meresap ke dalam $\operatorname{tanah}=$ F.K.h

Terdapat persamaan:

Volume air di dalam sumur $=\left(Q_{i}-Q_{0}\right)$. dt

Sehingga akan diperoleh persamaan berikut.

$$
H=\frac{Q}{F \cdot K}\left(1-e^{-\frac{F \cdot K \cdot T}{\pi \cdot R^{2}}}\right)
$$

Dengan H adalah kedalaman sumur (m), Q adalah debit aliran akibat hujan yang jatuh di atap bangunan $\left(\mathrm{m}^{3} / \mathrm{s}\right), \quad \mathrm{F}$ adalah faktor geometrik atau faktor bentuk $(\mathrm{m}), \mathrm{K}$ adalah koefisien permeabilitas tanah $(\mathrm{m} / \mathrm{s})$, $\mathrm{T}$ adalah $\mathrm{t}_{\mathrm{d}}$, lama hujan dominan (s), $\mathrm{R}$ adalah jari-jari sumur resapan (m).

Faktor geometrik (bentuk) adalah faktor yang memasukkan pengaruh bentuk sumur, jari-jari sumur, ketebalan dinding sumur dan letaknya terhadap lapisan tanah. Demikian juga luas bidang tanah sebagai media peresapan juga mempengaruhi faktor geometrik F. Pada penelitian ini kondisi sumur resapan yang direncanakan yaitu terletak pada tanah yang porus dengan dinding sumur resapan kedap air dan dasar sumur rata bersifat permeabel. Kondisi ini dapat digambarkan seperti Gambar 2, berikut.

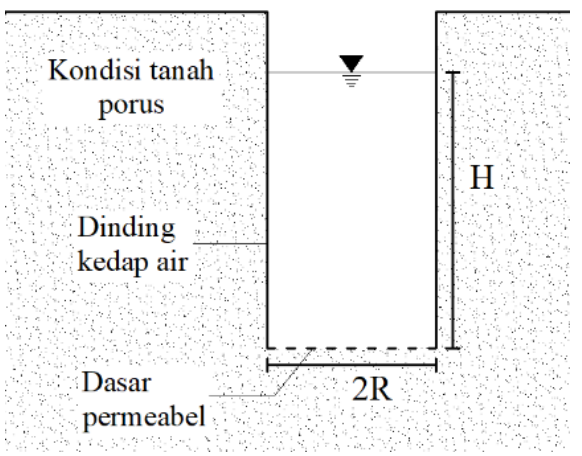

Gambar 2. Sketsa kondisi sumur dengan

$$
\mathrm{F}=2 \pi R
$$

Nilai faktor geometrik pada kondisi tersebut dapat dirumuskan seperti berikut.

$F=2 \pi R$

dengan $\mathrm{F}=$ faktor geometrik $(\mathrm{m})$ dan $\mathrm{R}=$ jarijari sumur (m).

Atau kondisi sumur resapan yang direncanakan terletak pada tanah yang porus

dengan dinding sumur resapan kedap air dan dasar sumur berbentuk setengah bola bersifat permeabel. Kondisi ini dapat digambarkan seperti Gambar 3, berikut.

Nilai faktor geometrik pada kondisi tersebut dapat dirumuskan seperti berikut.

$F=\pi^{2} R$

dengan $\mathrm{F}=$ faktor geometrik $(\mathrm{m})$ dan $\mathrm{R}=$ jarijari sumur (m). 


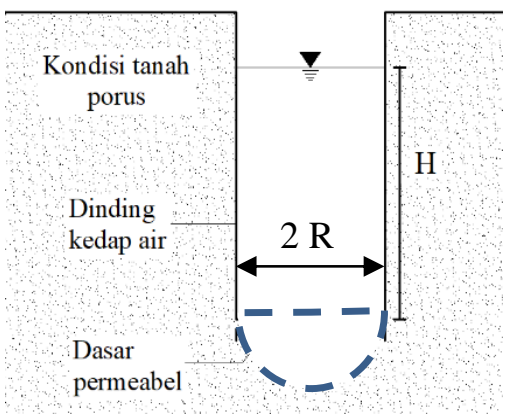

Gambar 3. Sketsa kondisi sumur dengan $\mathrm{F}=$ $\pi^{2} R$

Koefisien permeabilitas tanah adalah kemampuan butiran tanah untuk mengalirkan zat cair. Permeabilitas dinyatakan sebagai kecepatan zat cair mengalir melalui suatu bahan (tanah, bebatuan). Nilai permeabilitas bisa diperoleh dengan cara pengukuran di lapangan yaitu dengan metode menggunakan bahan tracer dan 2 sumur uji untuk diamati.
Atau bisa juga dianggap sama dengan laju infiltrasi konstan (Purnama, 2010).

Fungsi sumur resapan adalah untuk mengurangi limpasan permukaan suatu daerah dan merupakan usaha pelestarian air tanah.

Untuk menentukan jumlah sumur yang dibutuhkan maka harus dipertimbangkan lahan yang tersedia dan kapasitas 1 sumur yang direncanakan. Dari rumus Pers. (4), kapasitas 1 sumur resapan diturunkan menjadi sebagai berikut.

$$
\begin{aligned}
& Q_{1 \text { sumur }}=\frac{F \cdot K \cdot H_{1 \text { sumur }}}{1-e^{-\frac{F \cdot K \cdot T}{\pi \cdot R^{2}}}} \\
& n_{\text {sumur }}=\frac{Q}{Q_{1 \text { sumur }}}
\end{aligned}
$$

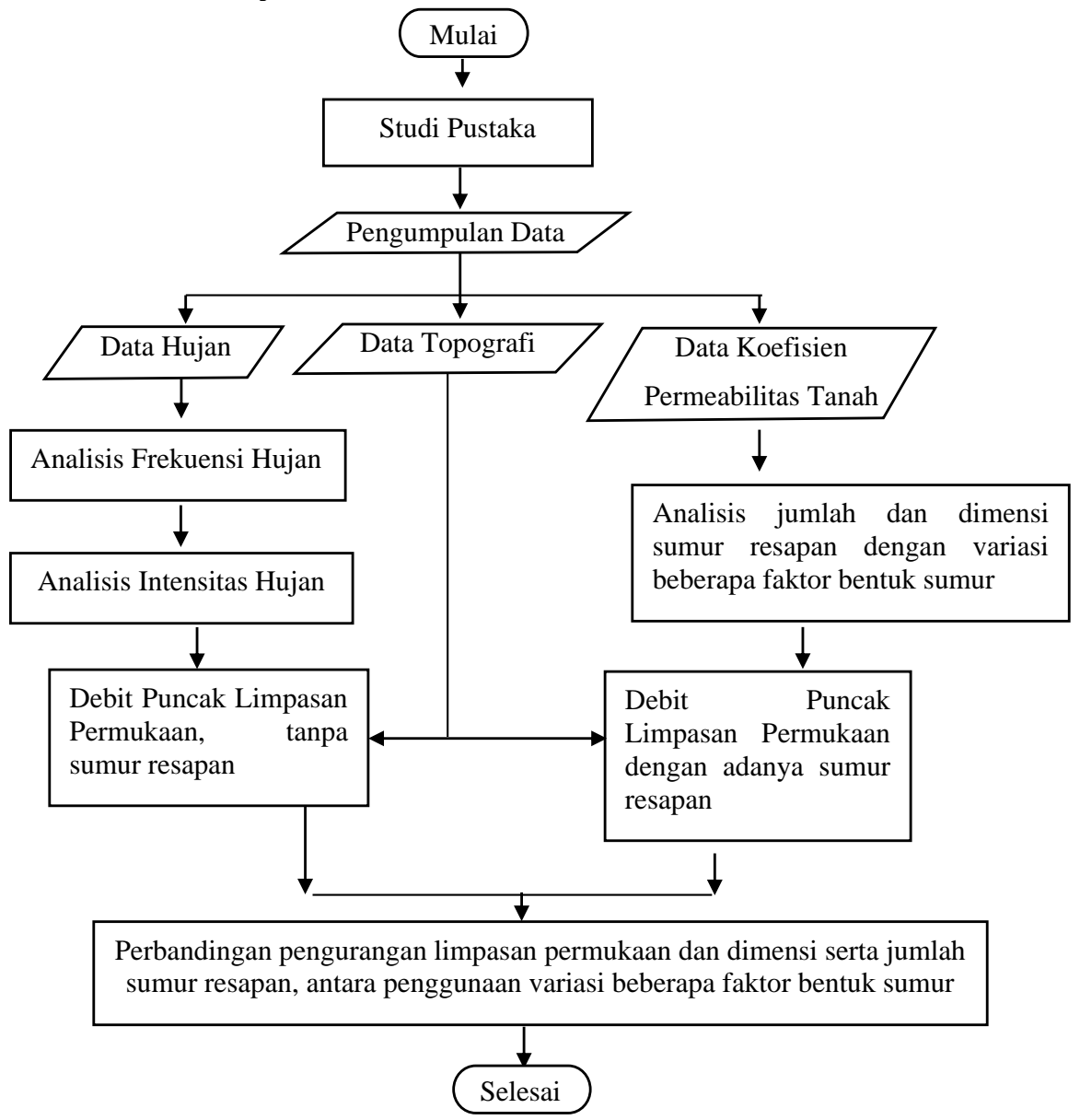

Gambar 4. Bagan alir penelitian 


\section{METODOLOGI}

Lokasi penelitian ada di Kampus Terpadu UII. Data yang diperlukan meliputi koefisien permeabilitas tanah, curah hujan harian maksimum tahun 2007 sd 2016 dari stasiun Prumpung, lay out bangunan dan saluran drainase, serta data topografi Kampus Terpadu UII.

Bagan alir penelitian dapat dilihat pada Gambar 4.

\section{ANALISIS DATA}

Bagan sistem saluran drainse Kampus Terpadu UII yang bermuara di kali Kimpulan adalah seperti berikut, lihat Gambar 5, di bawah ini.

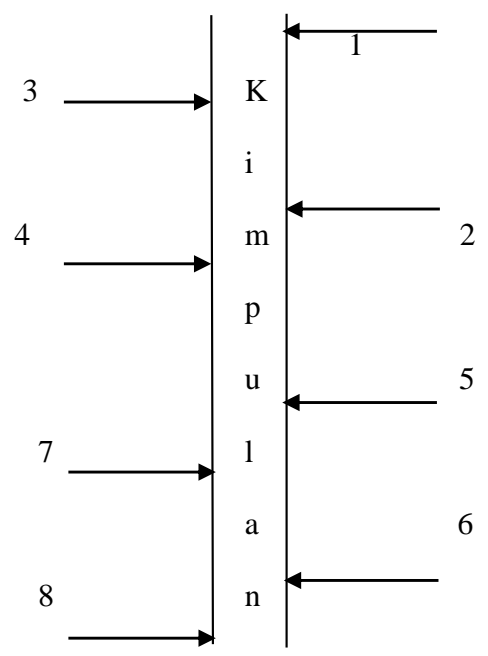

Gambar 5. Bagan sistem drainase Kampus Terpadu UII yang bermuara di Kali Kimpulan

Karakteristik saluran drainase terlihat pada Tabel 1, berikut.

Tabel 1. Karakteristik saluran drainase

\begin{tabular}{|c|c|c|c|c|}
\hline Saluran & $\begin{array}{c}\mathrm{L} \\
(\mathrm{Km})\end{array}$ & $\mathrm{S}_{0}$ & $\mathrm{C}$ & $\begin{array}{c}\mathrm{A} \\
(\mathrm{ha})\end{array}$ \\
\hline 1 & 0,188 & 0,0102 & 0,6 & 0,072 \\
\hline 2 & 0,232 & 0,0235 & 0,474 & 2 \\
\hline 3 & 0,198 & 0,0223 & 0,6 & 0,065 \\
\hline 4 & 0,254 & 0,0028 & 0,556 & 1 \\
\hline 5 & 0,073 & 0,0122 & 0,6 & 0,027 \\
\hline 6 & 0,176 & 0,0051 & 0,673 & 0,477 \\
\hline 7 & 0,227 & 0,0274 & 0,6 & 0,082 \\
\hline 8 & 0,177 & 0,0315 & 0,408 & 0,7 \\
\hline
\end{tabular}

\section{HASIL ANALISIS}

\section{Debit Limpasan Permukaan Tanpa Adanya Sumur Resapan}

Dari penelitian terdahulu (Wijaya, 2019) diketahui $\mathrm{R}_{5}$ adalah sebesar $122,836 \mathrm{~mm}$. Selanjutnya waktu konsentrasi dan intensitas hujan kala ulang 5 tahun, dapat dihitung, seperti terlihat pada Tabel 2, di bawah ini.

Tabel 2. Waktu konsentrasi dan intensitas hujan

\begin{tabular}{|c|c|c|c|c|c|}
\hline $\begin{array}{c}\text { Salu } \\
\text { ran }\end{array}$ & $\begin{array}{c}\mathrm{L} \\
(\mathrm{Km})\end{array}$ & $\mathrm{S}$ & $\begin{array}{c}\text { tc } \\
(\mathrm{jam})\end{array}$ & $\begin{array}{c}\mathrm{R} 5 \text { th } \\
(\mathrm{mm})\end{array}$ & $\begin{array}{c}\mathrm{I} \\
(\mathrm{mm} / \mathrm{jam})\end{array}$ \\
\hline 1 & 0,188 & 0,0102 & 0,1070 & 122,836 & 188,909 \\
\hline 2 & 0,232 & 0,0235 & 0,0913 & 122,836 & 210,088 \\
\hline 3 & 0,198 & 0,0223 & 0,0824 & 122,836 & 224,848 \\
\hline 4 & 0,254 & 0,0028 & 0,2220 & 122,836 & 116,163 \\
\hline 5 & 0,073 & 0,0122 & 0,0482 & 122,836 & 321,444 \\
\hline 6 & 0,176 & 0,0051 & 0,1328 & 122,836 & 163,566 \\
\hline 7 & 0,227 & 0,0274 & 0,0846 & 122,836 & 220,991 \\
\hline 8 & 0,177 & 0,0315 & 0,0662 & 122,836 & 260,247 \\
\hline
\end{tabular}

Berikutnya, dapat dihitung debit limpasan permukaan tanpa adanya sumur resapan, seperti terlihat pada Tabel 3, berikut.

Tabel 3. Debit limpasan permukaan tanpa adanya sumur resapan

\begin{tabular}{|c|c|c|c|c|}
\hline Saluran & $\mathrm{C}$ & $\begin{array}{c}\mathrm{I} \\
(\mathrm{mm} / \mathrm{jam})\end{array}$ & $\begin{array}{c}\mathrm{A} \\
(\mathrm{ha})\end{array}$ & $\begin{array}{c}\mathrm{Q} \\
(\mathrm{m} 3 / \mathrm{s})\end{array}$ \\
\hline 1 & 0,6 & 188,909 & 0,072 & 0,0227 \\
\hline 2 & 0,474 & 210,088 & 1,784 & 0,4935 \\
\hline 3 & 0,6 & 224,848 & 0,065 & 0,0244 \\
\hline 4 & 0,556 & 116,163 & 1,446 & 0,2594 \\
\hline 5 & 0,6 & 321,444 & 0,027 & 0,0145 \\
\hline 6 & 0,673 & 163,566 & 0,477 & 0,1459 \\
\hline 7 & 0,6 & 220,991 & 0,082 & 0,0302 \\
\hline 8 & 0,408 & 260,247 & 0,7 & 0,2065 \\
\hline
\end{tabular}

Debit Limpasan Permukaan dengan Adanya Sumur Resapan

Dengan lama hujan dominan adalah 2 jam, maka diperoleh intensitas hujan sebesar 26,8268 mm/jam. Kemudian dapat dihitung debit limpasan atap bangunan, seperti Tabel 4 .

Dengan terbatasnya lahan yang tersedia untuk dapat dibangunnya sumur resapan, dan juga dipengaruhi koefisien permeabilitas tanah, sumur resapan dengan (dimensi $\mathrm{D}=1,5 \mathrm{~m}$ dan $\mathrm{H}=4 \mathrm{~m}$ ) yang layak untuk dibangun adalah seperti pada Tabel 5 . 
Tabel 4. Debit limpasan atap bangunan

\begin{tabular}{|c|l|c|c|c|}
\hline Saluran & Bangunan & $\begin{array}{c}\mathrm{C} \\
\text { Koef. } \\
\text { Atap }\end{array}$ & $\begin{array}{c}\text { Luas } \\
\text { Atap } \\
\text { (ha) }\end{array}$ & $\begin{array}{c}\mathrm{Q} \\
\left(\mathrm{m}^{3} / \mathrm{s}\right)\end{array}$ \\
\hline 1 & - & & & 0 \\
\hline 2 & Rektorat & 0,9 & 0,119 & 0,0080 \\
\hline & GKU & 0,9 & 0,123 & 0,0082 \\
\hline & HI & 0,9 & 0,204 & 0,0137 \\
\hline & D3 Ekonomi & 0,9 & 0,127 & 0,0085 \\
\hline & FIAI (Baru) & 0,9 & 0,128 & 0,0086 \\
\hline 3 & - & & & 0,0000 \\
\hline 4 & TBK Lab & 0,9 & 0,133 & 0,0089 \\
\hline & FPSB \& FK & 0,9 & 0,366 & 0,0245 \\
\hline 5 & - & & & 0,0000 \\
\hline 6 & Masjid & 0,9 & 0,2 & 0,0134 \\
\hline 7 & - & & & 0,0000 \\
\hline 8 & Perpustakaan & 0,9 & 0,19 & 0,0127 \\
\hline
\end{tabular}

Dari Tabel 5, dapat dilihat bahwa semakin besar faktor geometrik, semakin berkurang jumlah sumur yang harus dibangun. Hal tersebut terjadi, karena faktor bentuk sumur berbanding terbalik dengan jumlah sumur resapan (lihat Pers. (7) dan (8), di depan).

Selanjutnya dapat dihitung debit limpasan permukaan (tanpa bangunan, dengan adanya sumur resapan, hujan yang jatuh di atap akan masuk ke sumur resapan), dapat dilihat pada Tabel 6, dibawah ini.

\section{Pengurangan Limpasan Permukaan}

Selanjutnya, pengurangan limpasan permukaan dapat dihitung (Tabel 7).
Dari Tabel 7, dapat dilihat bahwa pengaruh pemakaian faktor geometrik sumur resapan terhadap banyaknya sumur resapan adalah semakin besar faktor geometrik, semakin sedikit jumlah sumur resapan. Sedangkan pengaruh pemakaian faktor geometrik sumur resapan terhadap pengurangan limpasan permukaan adalah semakin besar faktor geometrik sumur resapan, tidak begitu berpengaruh pada pengurangan limpasan permukaannya. Persentase pengurangan limpasan permukaan hampir sama.

\section{PEMBAHASAN}

Faktor geometrik sumur resapan berbanding lurus dengan kapasitas sumur resapan, sedangkan dimensi dan jumlah sumur resapan berbanding terbalik dengan kapasitas sumur resapan. Berarti faktor geometrik berbanding terbalik dengan dimensi dan jumlah sumur resapan. Dengan menggunakan dimensi tertentu, semakin besar faktor geometrik yang digunakan (tergantung pemilihan jenis dan bentuk sumur resapan), akan semakin sedikit sumur resapan yang harus dibangun. Sebagai contoh, pada kompleks D3 Ekonomi, untuk jenis sumur resapan berdiameter $1,5 \mathrm{~m}$ dan tinggi $4 \mathrm{~m}$, dengan $\mathrm{F}=2 \pi R$ (atau $\mathrm{F}=4,7124$ m) dibutuhkan 8 buah, sedangkan sumur resapan dengan $\mathrm{F}=\pi^{2} R$ (atau $\mathrm{F}=7,4022 \mathrm{~m}$ ) dibutuhkan 7 buah. Demikian juga untuk kompleks-kompleks yang lain.

Tabel 5. Jumlah sumur resapan dan debit limpasan atap yang masuk ke sumur resapan

\begin{tabular}{|c|c|c|c|c|c|c|c|}
\hline \multirow[b]{2}{*}{ Saluran } & \multirow[b]{2}{*}{ Bangunan } & \multirow[b]{2}{*}{$\begin{array}{l}\text { Luas } \\
\text { Lahan } \\
\left(\mathrm{m}^{2}\right)\end{array}$} & \multirow[b]{2}{*}{$\begin{array}{c}\mathrm{K} \\
(\mathrm{m} / \mathrm{s})\end{array}$} & \multicolumn{2}{|c|}{ n Jumlah Sumur (unit) } & \multicolumn{2}{|c|}{ Q masuk sumur $\left(\mathrm{m}^{3} / \mathrm{s}\right)$} \\
\hline & & & & $\begin{array}{l}\mathrm{F} 1=2 \pi R \\
=4,7124 \mathrm{~m}\end{array}$ & $\begin{array}{l}\mathrm{F} 2=\pi^{2} R \\
=7,4022 \mathrm{~m}\end{array}$ & $\begin{array}{l}\mathrm{F} 1=2 \pi R \\
=4,7124 \mathrm{~m}\end{array}$ & $\begin{array}{l}\mathrm{F} 2=\pi^{2} R \\
=7,4022 \\
\mathrm{~m}\end{array}$ \\
\hline 1 & - & & & & & & \\
\hline 2 & Rektorat & 310 & 0,000049 & 6 & 5 & 0,0080 & 0,0080 \\
\hline & GKU & 256 & 0,000016 & 8 & 7 & 0,0082 & 0,0082 \\
\hline & HI & 382 & 0,0000065 & 13 & 13 & 0,0136 & 0,0089 \\
\hline & D3 Ekonomi & 814 & 0,000016 & 8 & 7 & 0,0085 & 0,0085 \\
\hline & FIAI (Baru) & 458 & 0,0000065 & 9 & 8 & 0,0086 & 0,0086 \\
\hline 3 & - & & & & & & \\
\hline 4 & Lab TBK & 310 & 0,000049 & 6 & 5 & 0,0089 & 0,0089 \\
\hline & FPSB \& FK & 427 & 0,0000065 & 14 & 14 & 0,0146 & 0,0096 \\
\hline 5 & - & & & & & & \\
\hline 6 & Masjid & 650 & 0,0000065 & 13 & 13 & 0,0134 & 0,0134 \\
\hline 7 & - & & & & & & \\
\hline 8 & Perpustakaan & 910 & 0,0000065 & 13 & 12 & 0,0127 & 0,0127 \\
\hline
\end{tabular}


Tabel 6. Debit limpasan permukaan (tanpa bangunan) dengan adanya sumur resapan

\begin{tabular}{|c|l|c|c|c|c|}
\hline Saluran & \multicolumn{1}{|c|}{ Bangunan } & $\mathrm{C}$ & $\begin{array}{c}\mathrm{I} \\
(\mathrm{mm} / \mathrm{jam})\end{array}$ & $\begin{array}{c}\text { Luas daerah (tanpa } \\
\text { luas atap bangunan) } \\
(\mathrm{ha})\end{array}$ & $\begin{array}{c}\text { Q Limpasan } \\
\text { permukaan } \\
(\mathrm{m} 3 / \mathrm{s})\end{array}$ \\
\hline 1 & - & 0,6 & 188,9086 & 0,0720 & 0,0227 \\
\hline 2 & Rektorat & 0,188 & 210,0885 & 1,0830 & 0,1188 \\
\hline & GKU & & & & \\
\hline & HI & & & & \\
\hline & D3 Ekonomi & & & & 0,0244 \\
\hline & FIAI (Baru) & & & & 0,1143 \\
\hline 3 & - & 0,6 & 224,8479 & 0650 & 0,0145 \\
\hline 4 & Lab TBK & 0,374 & 116,1630 & 0,9470 & 0,0642 \\
\hline & FPSB \& FK & & & & 0,0302 \\
\hline 5 & - & 0,6 & 321,4440 & 0,0270 & 0,0830 \\
\hline 6 & Masjid & 0,51 & 163,5655 & 0,2770 & 0,0820 \\
\hline 7 & - & 0,6 & 220,9910 & 0,5100 & \\
\hline 8 & Perpustakaan & 0,225 & 260,2468 & 0 & \\
\hline
\end{tabular}

Tabel 7. Pengurangan limpasan permukaan tanpa dan dengan adanya sumur resapan

\begin{tabular}{|c|c|c|c|c|c|c|}
\hline \multirow[t]{2}{*}{ Saluran } & \multirow[t]{2}{*}{ Bangunan } & \multirow{2}{*}{$\begin{array}{c}\text { Debit Limpasan } \\
\text { Permukaan tanpa } \\
\text { Sumur Resapan } \\
\left(\mathrm{m}^{3} / \mathrm{s}\right)\end{array}$} & \multicolumn{2}{|c|}{$\begin{array}{c}\text { Debit Limpasan Permukaan } \\
\text { dengan Sumur Resapan } \\
\left(\mathrm{m}^{3} / \mathrm{s}\right)\end{array}$} & \multicolumn{2}{|c|}{$\begin{array}{c}\text { Pengurangan Limpasan } \\
\text { Permukaan } \\
\left(\mathrm{m}^{3} / \mathrm{s}\right)\end{array}$} \\
\hline & & & $\begin{array}{c}\mathrm{F} 1= \\
4,7124 \mathrm{~m} \\
\end{array}$ & $\begin{array}{c}\mathrm{F} 2= \\
7,4022 \mathrm{~m}\end{array}$ & $\begin{array}{c}\mathrm{F} 1= \\
4,7124 \mathrm{~m}\end{array}$ & $\begin{array}{c}\mathrm{F} 2= \\
7,4022 \mathrm{~m}\end{array}$ \\
\hline 1 & - & 0,0227 & 0,0227 & 0,0227 & 0 & 0 \\
\hline \multirow[t]{5}{*}{2} & Rektorat & 0,4935 & 0,1189 & 0,1188 & 0,3746 & 0,3747 \\
\hline & GKU & & & & 0 & 0 \\
\hline & $\mathrm{HI}$ & & & & 0 & 0 \\
\hline & D3 Ekonomi & & & & 0 & 0 \\
\hline & FIAI (Baru) & & & & 0 & 0 \\
\hline 3 & - & 0,0244 & 0,0244 & 0,0244 & 0 & 0 \\
\hline \multirow[t]{2}{*}{4} & Lab TBK & 0,2594 & 0,1242 & 0,1237 & 0,1352 & 0,1357 \\
\hline & FPSB \& FK & & & & 0 & 0 \\
\hline 5 & - & 0,0145 & 0,0145 & 0,0145 & 0 & 0 \\
\hline 6 & Masjid & 0,1459 & 0,0642 & 0,0642 & 0,0817 & 0,0817 \\
\hline 7 & - & 0,0302 & 0,0302 & 0,0302 & 0 & 0 \\
\hline \multirow[t]{3}{*}{8} & Perpustakaan & 0,2065 & 0,0830 & 0,0830 & 0,1235 & 0,1235 \\
\hline & \multirow{2}{*}{ Jumlah } & 1,1970 & 0,4820 & 0,4814 & 0,7150 & 0,7156 \\
\hline & & & & & $(59,73 \%)$ & $(59,79 \%)$ \\
\hline
\end{tabular}

Faktor geometrik sumur resapan, ditentukan juga oleh luas bidang tanah sebagai media peresapan, semakin luas bidang tanah tersebut, akan semakin besar nilai faktor geometrik sumur $(\mathrm{F})$. Jenis sumur dengan bidang tanah lengkung setengah bola sebagai media peresapan mempunyai nilai faktor geometrik lebih besar dari pada jenis sumur dengan bidang tanah rata.

Faktor geometrik sumur resapan tidak begitu berpengaruh pada pengurangan limpasan permukaan. Semakin besar faktor geometrik pengurangan limpasannya adalah hampir sama, tidak banyak berubah, yaitu sebesar $59,73 \%$ pada sumur resapan dengan $\mathrm{F}=2 \pi R$ dan $59,79 \%$ pada sumur resapan dengan $\mathrm{F}=\pi^{2} R$. Hal tersebut terjadi, juga karena keterbatasan lahan yang tersedia. Syarat-syarat suatu lahan dapat dibangun sumur resapan adalah mempunyai muka air tanah dangkal yang cukup dalam (minimal 1,5 m pada musim hujan), mempunyai jarak 
yang cukup terhadap bangunan, mempunyai permeabilitas tanah $>2 \mathrm{~cm} / \mathrm{jam}$.

Koefisien permeabilitas tanah di Kawasan Kampus Terpadu adalah memenuhi syarat $>$ $2 \mathrm{~cm} / \mathrm{jam}$ atau $0,0000056 \mathrm{~m} / \mathrm{s}$. Elevasi muka air tanahnya juga cukup dalam sekitar $>7 \mathrm{~m}$. Berarti lahan di Kawasan Kampus Terpadu UII adalah layak dibangun sumur resapan.

Untuk menentukan jumlah sumur resapan yang dibutuhkan, tidak boleh dihitung dari kedalaman total dibagi dengan kedalaman 1 sumur, karena pendekatannya adalah unsteady flow. Namun yang benar adalah dihitung dari debit limpasan total dari atap yang masuk ke sumur dibagi dengan kapasitas 1 sumur.

Debit limpasan permukaan dengan adanya sumur resapan adalah debit limpasan permukaan dengan luasan daerah tanpa luas bangunan ditambah sisa debit limpasan dari atap yang tidak dapat seluruhnya masuk ke sumur resapan, karena adanya keterbatasan lahan yang layak untuk dibangun sumur resapan.

\section{KESIMPULAN DAN SARAN}

\section{Kesimpulan}

Dari uraian di atas dapat disimpulkan bahwa semakin besar faktor geometrik sumur resapan akan semakin kecil dimensi ataupun sedikit jumlah sumur resapan yang diperlukan. Sebagai contoh, pada kompleks D3 Ekonomi, untuk jenis sumur resapan berdiameter $1,5 \mathrm{~m}$ dan tinggi $4 \mathrm{~m}$, dengan $\mathrm{F}=2 \pi R($ atau $\mathrm{F}=4,7124 \mathrm{~m})$ dibutuhkan 8 buah, sedangkan sumur resapan dengan $\mathrm{F}=$ $\pi^{2} R$ (atau $\mathrm{F}=7,4022 \mathrm{~m}$ ) dibutuhkan 7 buah. Demikian juga untuk kompleks-kompleks yang lain.

Sedangkan terhadap pengurangan limpasan permukaan, penggunaan faktor geometrik yang semakin besar, tidak akan banyak berpengaruh, nilainya hampir sama, yaitu $59,73 \%$ pada sumur resapan dengan $\mathrm{F}=2 \pi R($ atau $\mathrm{F}=4,7124 \mathrm{~m})$ dan $59,79 \%$ pada sumur resapan dengan $\mathrm{F}=\pi^{2} R$ (atau $\mathrm{F}$ $=7,4022 \mathrm{~m}$ ).

\section{Saran}

Akan lebih baik, apabila dilakukan penelitian tambahan dengan model fisik sumur resapan, untuk memastikan pengaruh faktor geometrik sumur resapan.

\section{DAFTAR PUSTAKA}

Astuti, S. A. Y. (2020). "Kinerja Sumur Resapan Kampus Terpadu UII Tahun 2007 - 2016", Pertemuan Ilmiah HATHI XXXVII, Palembang.

Aziz, A, dkk. (2016). "Konservasi Air Tanah Melalui Pembuatan Sumur Resapan Air Hujan Di Kelurahan Maradekaya Kota Makassar", Journal INTEK, Vol 3 (2): 87-90.

Bahunta, L. dan Waspodo, R. S. B. (2019). "Rancangan Sumur Resapan Air Hujan sebagai Upaya Pengurangan Limpasan di Kampung Babakan, Cibinong, Kabupaten Bogor", Jurnal Sipil dan Lingkungan, Vol. 4, No. 1.

Purnama, S. (2010). "Hidrologi Air Tanah", Kanisius, Yogyakarta.

Prasojo, R. A. (2015). "Perbandingan Perancangan asumur Resapan Air Hujan menggunakan Metode Sunjoto dan SNI 03-2453-2002 pada Bangunan Komersial di Jl. Kaliurang Km 12 Sleman Yogyakarta”, Jurnal Teknisia.

Sunjoto. (2015). "Drainase Pro Air", Universitas Gadjah Mada, Yogyakarta.

Suripin. (2004). "Sistem Drainase Perkotaan yang Berkelanjutan", Andi Offset, Semarang.

Triatmojo, B. (2013). "Hidrologi Terapan", Beta Offset, Yogyakarta.

Wigati, R dan Ichwan, R. (2014). "Teknologi Sumur Resapan Dalam Kajian Pemaparan Hidrograf Banjir Sub DAS Ciujung", Jurnal Fondasi, Vol. 3, No. 1. 
Wijaya, T. P. (2019). "Pengaruh Sumur Resapan terhadap Pengurangan Debit Limpasan Permukaan di Kawasan Kampus Terpadu UII”, Konferensi Nasional Teknik Sipil (KONTEKS) 13, Medan. 